\title{
Dobrochna Ratajczakowa
}

Uniwersytet Adama Mickiewicza w Poznaniu

\section{O TEATRZE BULWAROWYM Szkic}

1.

Generał Karol Frankowski, kreślący w latach trzydziestych XIX wieku „fizjologiczny” portret Paryża, nazwał Bulwary „republiką federalną przemysłu”. To „450 numerów domów, to 1000 sklepów i kawiarń - a reprezentują kapitał co najmniej 300 milionów”. Zgodnie też z duchem epoki obliczał: „Na pięć procent od stu - i nie dałożby się łacno wykroić stąd budżetu jednego z królestw Związku Rzeszy Niemieckiej?". Przemysł, który reprezentowały Bulwary, był wywodzącym się z paryskich jarmarków przemysłem rozrywkowym. Na bezpośredni związek między nimi wskazują Chroniques des Petits Théâtres de Paris Nicolasa Braziera, autora piosenek, kupletów i wodewilów oraz dwutomowa „biografia” scen jarmarcznych, ujmująca ich legendę i rysująca proces ich przekształcania się w sceny bulwarowe. ${ }^{2}$ Transformacja powodowała zmianę ich lokalizacji i organizacji, nie naruszając rozrywkowej funkcji, natomiast wyostrzając komercyjną estetykę, którą z czasem rozwinęli i utrwalili bulwarowi autorzy, aktorzy, reżyserzy i widzowie. To dzięki nim teatr stał się przedsięwzięciem komercyjnym na miarę dziewiętnastowiecznej mieszczańskiej publiczności, a potentaci bulwaru, Guilbert de Pixérécourt i (zwłaszcza) Eugène Scribe, dokonując standaryzacji elementów tekstów zmienili przygotowanie spektakluw rodzaj przemysłu. ${ }^{3}$

\footnotetext{
K. Frankowski, Moje wędrówki po obczyźnie. Paryż, oprac. i wstęp J. Odrowąż-Pieniążek, red. W. Zawadzki, Warszawa 1973, t. 2, s. 134.

2 N. Brazier, Chroniques des Petits Théâtres de Paris, Paris 1883, vol. 1, s. 304-305. Trzeba jednak odnotować, że Pierre Gascard widzi dziedzictwo bulwaru w starych spektaklach misteryjnych i farsowych. Jego zdaniem przedstawienia paryskich jarmarków były ich ,awatarem”, zajmując miejsce między klasyczną produkcją dramatyczną a włoskimi bufoneriami. Zob. P. Gascar, Le Boulevard du Crime, Paris 1980, s. 59.

3 M. Verssillier, La crise du théâtre privé, préface de H. Guitton, Paris 1973, s. 46.
} 
Kiedy w 1759 Viarme de Pontcarré, prévôt des Marchands (burmistrz Paryża) zezwolił na otwarcie na bulwarach bilardów i szynków, zapoczątkował powstanie multisystemowego kompleksu konsumpcyjno-rozrywkowego. Był to zalążek wzorowanego na jarmarcznym kalejdoskopie przyszłego dziewiętnastowiecznego zbioru atrakcji, w którym swe miejsce znalazły również teatry. Jak podaje Maurice Descotes, jeden z protestów Teatru Francuskiego przeciwko działaniom Nicoleta, antreprenera jarmarcznej trupy Wielkich Skoczków i Tancerzy na Linie, zarazem pierwszego „lokatora” Bulwarów, doczekał się takiej odpowiedzi ministra: „Potrzebne są spektakle dla ludu”. Istotnie, Paryż rozrastał się szybko, między rokiem 1831 a 1846 doszedł do miliona mieszkańców, a ewolucja publiczności (jak twierdzi Descotes) poprzedziła rewolucję. ${ }^{5}$

Fenomen zwany Teatrem Bulwarowym wpisuje się w ramę kultury popularnej, która wbrew pojawiającym się przekonaniom nie narodziła się pod koniec XIX wie$\mathrm{ku}^{6}$, lecz istniała niemal ,od zawsze” i z tego powodu dla badacza sztuki masowej, Noëla Carrolla, stanowi pojęcie (i zjawisko) ahistoryczne. W wieku XIX sztuka należąca do tej kultury zyskała postać sztuki masowej ze względu na sposób produkowania i rozpowszechniania. ${ }^{7}$ Jej rozwój nie musiał się łączyć z procesem zapożyczania form z kultury wysokiej, co niejednokrotnie sugerowano, miała bowiem formy własne i własną estetykę. Wprawdzie pojedynczy teatr jako izolowany punkt w przestrzeni miasta nie jest dla Carrolla medium sztuki masowej ${ }^{8}$, ale sprawa przedstawia się inaczej w przypadku paryskiego Bulwaru, stającego się miejscem koncentracji heterogenicznych praktyk konsumpcyjno-rozrywkowych, funkcjonujących jako swoista sieć. Nie bez powodu generał Frankowski traktuje Bulwary jako ,przemysł”, można też je nazwać sektorem handlowo-usługowo-rozrywkowym i artystycznym, potraktować jako masową formę ekspresji ówczesnej postaci kultury popularnej, łączącej w akcie kolektywnej konsumpcji różne pola wytwórczo-odbiorcze. Pasaże, sklepy, restauracje, traktiernie i kawiarnie, obrazy panoptików, panoram i dioram, sale gier, kręgli i bilardów, seks w domach publicznych znajdujących się na wyższych piętrach pasażów - wszystkie te elementy współtworzą sieć multisystemu zawdzięczającego nie jaki pozór spójności przestrzennie określonej konsumpcji, która integruje różne segmenty bulwarowych atrakcji i produkuje zysk. Powstaje „rozpisana” na ulice i miejsca rozległa kultura uczestnictwa, w której zacierają się granice między autorami i odbiorcami, producentami i widzami.

Michel de Certeau definiuje kulturę popularną jako "sztuki praktykowania" tego lub tamtego, to znaczy łączące i użytkujące czynności konsumpcyjne.

4 M. Descotes, Le public théâtrale et son histoire, Paris 1964, s. 209.

5 Ibidem, s. 213.

6 Zob. N. Abercrombie, S. Lash, B. Longhurst, Przedstawienie popularne. Przerabianie realizmu, przekł. E. Mrowczyk-Hearfield, [w:] Odkrywanie modernizmu. Przekłady i komentarze, red. i wstęp R. Nycz, Kraków 1998, s. 407.

7 N. Carroll, Filozofia sztuki masowej, przekł. M. Przylipiak, Gdańsk 2011, s. 184.

8 Ibidem, s. 189, 200. 
Praktyki te odnoszą się do „codziennego" ratio, będącego sposobem myślenia włączonym w sposób działania, sztuką kombinacji nieodłączną od sztuki używania”. ${ }^{9} \mathrm{Z}$ kolei konsumpcję traktuje de Certeau jak ,inną produkcję”, ,podstępną, rozproszoną, przenikającą wszędzie, cichą i jakby niewidoczną, gdyż nie ujawnia się za pomocą własnych produktów, ale przez sposoby używania produktów narzuconych przez dominujący system ekonomiczny". ${ }^{10}$ Stanowiąca ważną część tej kultury i jej konsumpcji sztuka popularna identyfikuje się zarówno dzięki różnicy w stosunku do tzw. sztuki wysokiej, jak też dzięki odmianom krążących w jej ramach historycznie determinowanych idei, form, gatunków, obrazów, tematów, scenicznych idiomów, kodów zachowań. Wymiar ponadczasowy ma jej związek z pieniądzem, wsparty przez wpisane w nią typy kapitału: kapitału pracy i kapitału pamięci o jej własnej tradycji. Związek ten niekiedy, w skutek dominacji „zdjętej” z dzieł awangardowych „miary”sztuki autonomicznej, bezwzględnie pozytywnie wartościowanej - powoduje jak najgorsze traktowanie sztuki popularnej zwłaszcza w jej masowej i komercyjnej odmianie. Nie tylko jest źle oceniana jako podwójnie pozbawiona wartości - bo merkantylna i popularna ${ }^{11}$, ale też $\mathrm{z}$ powodu jej cech - schematyczności, powtarzalności i przystępności. To cena za jej powszechny adres zapewniający przeżycie paryskiemu sektorowi prywatnych scen, to znaczy Teatrom Bulwarowym. Wpisują się one doskonale w system zinstytucjonalizowanej, totalnej i hybrydycznej konsumpcji i rozrywki, wielozmysłowej, wieloodmianowej i wieloważnej, system zwrotny, cyrkularny, który miał charakter systemu run into. Determinowała go sieć heterogenicznych punktów konsumpcji, gromadzących ludzi wszystkich klas i zawodów, połączonych specyficznym bulwarowym, performatywnym sposobem bycia, znamiennym dla królestwa „esprit boulevardier”. ${ }^{12}$

Pierwsze znaczenie słowa „boulevard” to przedmurze, potem - szeroka ulica wysadzana drzewami, niejako zachęcająca do spacerów. Stąd boulevardier, spacerowicz, włóczykij bulwarowy. Znamienną fałszywą etymologię Eduarda Fourniera, autora Chroniques, légendes des rues de Paris (1864), podaje Walter Benjamin: „boulevard to tylko wariant słowa bouleversement”, co znaczy wstrząs, przewrót, zmiana, nawet - rewolucja. ${ }^{13}$ Rzeczywiście, w pewnym sensie Bulwar rewolucjonizował poprzednią sytuację teatrów. Powstała tu bowiem strefa prywatnych scen i ona właśnie, wyjęta $z$ całego konsumpcyjno-rozrywkowego multisystemu, stanie się przedmiotem mej uwagi. Ona też z czasem uniezależni

$9 \quad$ M. de Certeau, Wynaleźć codzienność. Sztuki działania, przekł. K. Thiel-Jańczuk, Kraków 2008, s. XXXIX.

10 Ibidem, s. XXXVI.

11 P. Bourdieu, Reguly sztuki. Geneza i struktura pola literackiego, przekł. A. Zawadzki, Kraków 2001, s. 335 .

12 Guide littéraire de la France, Paris 1964, s. 54; zob. B. Brzozowska, Spadkobiercy flaneura. Spacer jako twórczość kulturowa - wspótczesne reprezentacje, Łódź 2009, s. 42.

13 W. Benjamin, Pasaże, red. R. Tiedemann, przekł. I. Kania, posłowie Z. Bauman, Kraków 2005, s. 169. 
się od sieci, w ramach której zaistniała. Standaryzacja i komercyjność będą tu determinować zarówno styl przedstawianych dramatów (Michel Corvin zwie go „dramaturgią efektu”), jak wypracowywany przez lata sceniczny idiom oparty na wspólnym z widownią systemie poglądów i wartości. ${ }^{14}$

Popularny repertuar bulwarowy, zwykle traktowany jako pozbawiony ,większych ambicji artystycznych" ${ }^{15}$, był u swego początku skierowany po prostu do widowni miejskiej, która nie utraciła jeszcze swych ludowych korzeni i która doskonale znała estetykę jarmarku, wpływającą przez szereg lat na kształt pierwszego Bulwaru. Uformowały go dwa główne, niezwykle żywotne gatunki, melodramat i wodewil, które energetyzowały publiczność. Rządziła nimi praktyczna i zarazem „pstra” estetyka oparta na hybrydycznej zasadzie varietas, odwołująca się do fundamentalnej dla jarmarku relacji popytu/podaży. Pieniądz, wpisany w poetykę przedstawień, przepływał tu dwustronnie między sceną a widownią, w pierwszym rzędzie decydując o sukcesie realnym, determinowanym przez upodobania widzów, a dopiero w dalszym planie o ewentualnym sukcesie symbolicznym, jaki na przykład stał się udziałem genialnego mima teatru Funambules, Gaspara Deburau. Podziwiali go i uwielbiali nie tylko zwykli widzowie, tzw. mali ludzie, ale też ówcześni koryfeusze romantyczni - Gérard de Nerval, Théophile Gautier, Charles Nodier, Théodore de Banville, Eugène Delacroix. Sztuki pokazywane na bulwarze były dalekie od zasad literatury dramatycznej i pozostawały zwykle zbiorem danych do scenicznego performansu, wymagającego współpracy z publicznością. Wskutek tego liczące na ,publiczność dnia” spektakle miały krótki cykl produkcyjny i jako działanie małego ryzyka mogły kreować zysk, co z kolei definiowało Bulwar jako miejsce konsumpcji scenicznego towaru, kontrastowane $\mathrm{z}$ innymi współczesnymi mu teatrami, w pierwszym rzędzie subwencjonowanymi, a z czasem z tymi, których kształt przede wszystkim określi działalność artystyczna. ${ }^{16}$ Nie znaczy to jednak, że powstające tu przedstawienia były bezwartościowe, ale że najczęściej ich wartość tkwiła poza tradycyjnym tekstem dramatycznym i poza literaturą.

2.

Bulwar, ujmowany jako całościowa przestrzeń konsumpcyjnych atrakcji ze swymi pasażami, salami gier, kawiarniami, traktierniami, sklepami, ulicznymi przekupniami (w 1882 otwarto tu Muzeum Figur Woskowych), był szczególnym przypadkiem miejskiej topografii, znajdował się wszak ,we wnętrzu toponimicznym”, jak pisze Catherine Naugrette-Christophe. ${ }^{17}$ Był jednak także bytem pa-

14 M. Corvin, hasło Boulevard (le théâtre de), [w:] Dictionnaire encyclopédique du théâtre, t. 1, Paris 2001, s. 234. 1976, s. 452.

15 Zob. hasło Teatr bulwarowy, [w:] Słownik terminów literackich, red. J. Sławiński, Wrocław

16 G. Gengembre, Le théâtre français au XIX siècle (1789-1900), Paris 1999, s. 141.

17 C. Naugrette-Christophe, Paris sous le Second Ėmpire. Le théâtre et la ville. Essai topographie théâtrale, Paris 1998, s. 199. 
radoksalnym, tworzącym własną kulturę uczestnictwa w kadrze podwojonego centrum. Projektował przecież zdynamizowane faktyczne i symboliczne centrum popularnej kultury i sztuki w ustabilizowanym centrum europejskiej metropolii, która stanowiła jednocześnie teatralną stolicę świata. Niejako kreował scenę w kadrze sceny, a obramowujące ją budynki teatrów stawały się swoistą scenografią przestrzeni tłumnego miejskiego spektaklu. Powstawało coś na kształt wielkomiejskiego parku rozrywki, zjawisko realne, konkretne, część geografii miasta, lecz jednocześnie pojęcie historyczno-kulturowe i społeczne, historyczno-teatralne, genologiczne i estetyczne, zarazem jednak pod każdym względem niskie w ramach jego przeszło dwustuletniej egzystencji i historycznej hierarchii fenomenów kulturowych. Określały go mieszane kategorie - lokalizacyjna, finansowo-organizacyjna, społeczno-obyczajowa i psychologiczna.Wszak bulwarowy flaneur, „postać przejściowa”, ,inauguruje strategie prywatności” „w łonie przestrzeni publicznej". ${ }^{18}$

Pięć spośród jedenastu bulwarów miało sale teatralne: na bulwarze Montmartre Théâtre de Variétés (przeniesiony z Palais-Royal dekretem Napoleona w 1807), Théâtre Beaumarchais na bulwarze Beaumarchais, Gymnase na bulwarze de Bonne-Nouvelle, Théâtre de la Porte-Saint-Martin oraz Ambigu-Comique na bulwarze Saint-Martin - inne gnieździły się na najsłynniejszym z nich bulwarze duTemple, zwanym Bulwarem Zbrodni. Na bulwarze Capucines, Madeleine i des Italiens mieściły się najbardziej znane kawiarnie - Café du Grand Balcon, Café Anglais, Riche, Hardy, le Maison Tortoni, od 1852 Bains Chinois o teatralnej dekoracji. Bulwar du Temple też posiadał swoje kawiarnie, z najsłynniejszą Café Turc, a z czasem poszczególne teatry otwierały własne - miały je Gaîté, Cirque Olympique czy Folies-Dramatiques. Z tyłu Bulwaru des Italiens znajdowała się Opéra-Comique. ${ }^{19}$

Bulwar w istotny sposób decydował o rynku teatralnym przez cały wiek XIX i lata międzywojenne. Nie stanowił monolitu - zmiany w jego strukturze pozwalają na wyodrębnienie przynajmniej trzech odmian. W pierwszym okresie swej działalności, przypadającym na lata restauracji i monarchii lipcowej, kiedy to stanowił część pierwotnego multisystemu, miał głównie charakter melodramatyczno-wodewilowy (choć grywał też pantomimy, feerie, mimodramy, komedie), a identyfikował się przez opozycję do tradycyjnej sztuki akademickiej i wystąpień romantycznych liberałów. Dwa podstawowe gatunki musiały się wtedy zmierzyć z nowym zjawiskiem, jakim była masowa, ludowo-mieszczańska widownia, dzieląc między siebie obszar jej emocjonalizmu na teren lęków i łez (czyli melodramat) oraz teren zabawy i śmiechu (więc wodewil). Zanim Georges Haussmann zaczął w roku 1852 wyburzać stare ludowe dzielnice straszliwej nędzy, na samym

18 A. Corbain, Kulisy, przekł. W. Gilewski, [w:] Historia życia prywatnego, t. 4: Od rewolucji francuskiej do I wojny światowej, red. M. Perrot, Wrocław 2006, s. 535.

19 Wszystkie informacje za C. Naugrette-Christophe, op. cit., s. 29-30. 
Bulwarze du Temple, który miał ucierpieć najbardziej, działało 7 teatrów, poprzedzielanych kawiarniami, kabaretami, pasażami.

Pasaże, modny zwłaszcza w latach dwudziestych i trzydziestych stulecia „rodzaj zamkniętych mikroświatów o urozmaiconej ofercie rozrywkowej”20, łączyły różne formy ówczesnej konsumpcji, a teatr po prostu stanowił jedną z nich. Wśród scen Boulevard du Crime był Théâtre Lyrique, otwarty w $1851 \mathrm{w}$ sali Théâtre Historique Aleksandra Dumasa, Théâtre Imperial du Cirque, zajmujący salę zbudowaną w 1827 dla Cyrku Olimpijskiego (to tu w 1852 pokazano dramat wojskowy w 5 aktach i 19 obrazach Bonaparte w Egipcie Frédérica Labrousse'a). Dalej mamy Folies-Dramatiques, od 1831 w starym budynku Ambigu-Comique, który przeniósł się na bulwar Saint-Martin. Razem z Théâtre Gaité zajmował centralne miejsce tego bulwaru. Gaîté był najstarszym teatrem, otwartym w 1760 roku przez antreprenera skoczków Nicoleta, choć sala była nowa, zbudowana w 1835 po pożarze starej (jeszcze z 1807). 1818 widzów podziwiało tu melodramaty i wodewile. Obok było królestwo pantomimy, czyli budynek Funambules na przeszło 750 widzów, uruchomione w 1816 miejsce przyszłych tryumfów Gaspara Deburau, dalej stał budynek o zmiennej nazwie - najpierw był to Théâtre des Associés, potem Sans-Prétention i kawiarnia Apollo z piosenkami i małymi arlekinadami, z czasem osiadł w nim stały rywal Funambules, Théâtre des Acrobates Madame Saqui, który następnie przekształcił się w ThéâtreduTemple, a od 1841 w Délassements-Comiques (900 miejsc). Za nim działała od 1830 mała sala z 608 miejscami zwana przez widzów Petit Lazzari, postawiona na gruzach spalonego Variétés Amusantes zbankrutowanego samobójcy, Ange Lazzari. ${ }^{21}$ Trzy ostatnie teatry miały wspólny daszek nad wejściem.

Znamienna dla tej przestrzeni determinanta estetyczna wywodziła się z bulwarów starego Paryża - pisze Michel Corvin ${ }^{22}$ i ustanawiała popularny teatr dla każdego. Był to Paryż ludowy, uprawiający coś na kształt niekończącego się jarmarcznego święta, które współtworzyła „mieszanina potworności, okrucieństwa, popisów zręcznościowych - w połączeniu z bezustanną wrzawą jarmarcznego placu wytwarzała atmosferę wesołości [...] Za straganami i stoiskami wznosiły się liczne teatrzyki, poustawiane tuż obok siebie". ${ }^{23}$ Jak zapisał generał Frankowski: „drzwi w drzwi, kasa przy kasie”. ${ }^{44}$ Było to miejsce tzw. „théâtres de genre” (gatunkowych) i ,spectacles de curiosités” (osobliwości). ${ }^{25}$ Zezwolenia na określony repertuar nie tylko łączyły teatry z pewnymi gatunkami, lecz także prowadziły do wspomagającej zyski dywersyfikacji repertuaru. I tak Cyrk Olimpijski grał

20 M. Omilanowska, Światynie handlu. Warszawska architektura komercyjna doby wielkomiejskiej, Warszawa 2004, s. 210.

21 C. Naugrette-Christophe, op. cit., s. 40-49.

22 M. Corvin, op. cit., s. 232.

23 S. Kracauer, Jacques Offenbach i Paryż jego czasów, przekł. A. Sąpoliński, Warszawa 1992, s. 27.

24 K. Frankowski, op. cit., s. 138.

25 C. Naugrette-Christophe, op. cit., s. 30. 
najpierw pantomimy, potem pantomimy z dialogami, tzw. mimodramy; w Folies-Dramatique prezentowano wszystko prócz pantomim, głównie zresztą wodewile i feerie; z kolei Funambules w 1815 mógł wystawiać pantomimy bez monologów i dialogów, a po 1837 - też arlekinady i wodewile; Délassements-Comique w latach 1841-1862 pokazywał komedie, wodewile, dramaty, feerie, revues. Gaité stało melodramatami, podobnie jak Ambigu-Comique w latach 1789-1827, nie mówiąc o Théâtre de la Porte-Saint-Martin, dokąd w latach trzydziestych przenieśli się romantycy. Ten złoty czas romantycznego dramatu i dyrekcji Harela, z wielkimi aktorami - Frédérikiem Lemaîtrem, Marie Dorval, Pierre'em Bocage'em zmienił rozkład sił na bulwarach, choć sukces sceny przy starej, jeszcze siedemnastowiecznej bramie św. Marcina, był nie tak czysty ze względu na złą reputację bulwarów. ${ }^{26}$

W pierwszych latach bulwaru z tradycji jarmarku wywodzili się zapowiadacze (każdy teatr miał własnych), południowe parady, które reklamowały wydarzenia oraz dwa (lub więcej) przedstawienia dziennie, ze zróżnicowaną widownią. O ile na spektakle odbywające się od 6 po południu do 9 wieczorem przybywała publiczność ludowa, robotnicy, rzemieślnicy, drobni kupcy, przekupki z targu Temple, gryzetki, ulicznicy, o tyle następne, między 12 a $2 \mathrm{w}$ nocy gromadziły widownię mieszczańską, urzędników, adwokatów, arystokratów incognito. ${ }^{27}$ Spektakle nie były drogie, pierwsze miejsca w Funambules kosztowały 75 centymów, pierwsza galeria 60 , amfiteatr 40 , parter 30 , drugie miejsca - tylko 20 centymów. ${ }^{28} \mathrm{Z}$ jarmarcznej estetyki wywodziły się zarówno przyciągające nazwy teatrów, jak trickowe inscenizacje, przydatne przy pantomimach, mimodramach, feeriach, małych i dużych arlekinadach, zwłaszcza tych w stylu angielskim, rewiach, wodewilach, melodramatach - początkowo głównego gatunku bulwaru. Niezależnie od tego, że wczesne melodramaty (zwane też pantomimami i komediami heroicznymi, feeriami czy pantomimami-feeriami) należą do de Martellière'a (Robert herszt zbójców, 1791, przeróbka Schillera), Audinota (Podoficer kawalerii) czy de Tréogate'a (grywany w Polsce Las okropny czyli Rozbójnicy kalabryjscy, 1797), swą świetność zawdzięczał gatunek Guilbertowi de Pixérécourt. On pierwszy użył tej nazwy w jej nowoczesnym znaczeniu w sztuce Wiktor czyli Dziecię lasu $(1797)^{29}$, a jego pozycję, potwierdzoną przez szereg tryumfujących melodramatów, utrwaliła Celina czyli Dziecię tajemnicy. ${ }^{30}$ „W roku 1800 - pisze Descotes - bulwar, to był melodramat. A melodramat, to był Guilbert de Pixérécourt". ${ }^{31}$

26 M. Descotes, Le drame romantique et ses grands créateurs (1827-1839), Paris 1955, s. 197; A. Ubersfeld, Le drame romantique, Paris 1993.

27 J. Švehla, Deburau, Pierrot nieśmiertelny, przekł. M. Erhardt-Gronowska, Warszawa 1983, s. 120.

28 Ibidem, s. 131, 141.

29 W. G. Hartog, Guilbert de Pixérécourt. Savie, son melodrame, sa technique et son influence, Paris 1913, s. 44.

30 P. Ginisty, Mélodrame, Paris 1910, s. 13-14.

31 M. Descotes, Le public ..., op. cit., s. 220. 
$\mathrm{Na}$ bulwarze zamiast aktów dominowały obrazy, podstawowe tworzywo gatunku, a jak obrazy - to inscenizacja, przez Antoinette Allévy-Viala nazwana Muzą Bulwarów. ${ }^{32}$ To ona, uwodząc widownię, decydowała o wyposażeniu teatrów w wózki, trapy szczelinowe, plany, podciągi, a sześciu maszynistów zatrudnionych w Funambules w 1855 pokazuje jej znaczenie. ${ }^{33} \mathrm{Z}$ jarmarkiem pozostawała spowinowacona performatywna konstrukcja zestandaryzowanych dzieł, zakładająca wysoki stopień sprawczości w warunkach przedstawienia i skoncentrowany odbiór widowni. Spektaklami rządziła akcja, często cudowna, legendowa, realistyczna i okrutna. Szeroko rozumiany idealistyczny realizm był bowiem ważny dla kultury popularnej jako powszechny system oznaczania i uwiarygodniający element spektaklu. ${ }^{34}$ Czynił on wiarygodną (co nie znaczy prawdopodobną) także feerię, pantomimę, wodewil, farsę czy późniejszą operetkę, usprawiedliwiając efekty płynące z zachwiania wiarygodności lub wręcz z jej (także wiarygodnego) braku.

Bogacący się na spektaklach i płacący grosze aktorom antreprenerzy przybywali skądkolwiek - Nicolas Michel Bertrand i Jean Jacuqes Fabien zanim wznieśli budynek Funambules sprzedawali jajka i masło oraz parasole; podobnie autorzy - Emile Chavalet był urzędnikiem Ministerstwa Wojny, urzędnikiem był Ludovic Halevy, a Lafargue pisarzem sądowym. Spektaklami rządziła profesjonalna klaka, która (zdaniem Jean Duvignaud) była - obok stylu gry - znamienną cechą bulwaru. ${ }^{35}$ Każdy teatr miał własną, a jej szef stawał się „mistrzem sukcesu”. Wszak polaryzował uwielbienie, dookreślał gusta, komenderował aplauzem, „zastępował sąd krytyczny przez akt fizyczny". ${ }^{36}$ Aktor mógł stać się podwójnym niewolnikiem - widowni i sukcesu stworzonego przez siebie typu, utrwalonego przez aplauz klaki. Przykładem takiego „niewolnika” jest Frédéric Lemaître, twórca postaci Roberta Macaire ${ }^{37}$, scenicznego wizerunku człowieka nowoczesnego, posiadającego nadzwyczajne zdolności do szalbierstwa, aobciążonego brakiem moralności i oddanego kultowi pieniądza. W serii Daumiera Macaire stawał się przewrotnym adwokatem, bankierem, dziennikarzem.

W Paryż Ludwika Filipa, w instytucję bulwarowego teatru, w jego autorów wcielał się pieniądz, tworząc uniwersum oparte na wierze w jego moc. Dlatego też - jak zauważa Descotes - „w oczach współczesnych Scribe jest faktycznie prawdziwym i jedynym wielkim pisarzem teatru." Hugo czy de Vigny to młodzi szaleńcy, „marzyciele zdolni wzniecać kłótnie każdego wieczoru”,

32 M. A. Allévy-Viala, Inscenizacja romantyczna we Francji, przekł. W. Natanson, przedmowa Z. Raszewski, Warszawa 1958, s. 98.

33 J. Svehla, op. cit., s. 127.

34 N. Abercombie, op. cit., s. 383.

35 J. Duvignaud, L'acteur. Esquisse d'une sociologie du comédien, Paris 1965, s. 136.

36 Ibidem, s. 138.

37 Zob. O. Krakovitch, Robert Macaire ou la grande peur des censeurs, „Europe” 1987 nr 703-704 (zeszyt poświęcony melodramatowi). 
wywołujący,,hałas powierzchowny i przejściowy”. Natomiast „solidny i trwały jest Scribe”, doskonała realizacja ducha école de bon sens, skądinąd nazywany ironicznie przez tamtych „wielkim człowiekiem portierów”. ${ }^{38}$ Jeśliby uznać za Bourdieu, że o wartości dzieła sztuki decyduje nie tyle artysta, ile pole produkcji jego dzieł, więc swoiste „uniwersum wiary” w tę wartość, budzące z kolei wiarę w moc twórczą autora, trzeba by uznać wielkość Scibe'a. ${ }^{39}$ I przyjąć, że jest przez nas niedoceniany.

Od początku gatunki dzieliły Bulwar Zbrodni na Boulevard comique i Boulevard sérieux, ale oba oferowały rozrywkę i zapewniały stabilność układu. Mimo że teatry zmieniały zarówno nazwy, jak właścicieli, że budynki paliły się i były odbudowywane, mieszczące się w nich sceny odnosiły sukcesy i porażki, wykształcił się pewien model bulwarowej instytucji. Widać to na przykładach trzech najstarszych i najlepszych scen: Ambigu-Comique, Porte-Saint-Martin i Gaîté. Na samej górze hierarchii stał właściciel sali i przywileju. Po nim szedł reżyser generalny i dwóch reżyserów. W Gaîté było inaczej - na czele stał administrator, następnie dyrektor i reżyser. W Ambigu do tego obszaru dołączał sufler i kopista. Liczba aktorów i aktorek we wspomnianych teatrach jest porównywalna - 13 aktorów w Ambigu, 10 w Porte-Saint-Martin obok 8 aktorek, w Gaité odpowiednio 14 i 6 . Konieczny był też balet, bez którego nie mógł się obejść melodramat - wszak pogłębiał akcję, współtworzył obrazy, stanowił jedną z atrakcji. Ważna okazywała się zatem nie tylko orkiestra czy maszynista, ale też maître de ballets i zespoły tancerzy. W Gaîté tańczyło 6 pierwszych tancerzy z 14-osobowym zespołem i 11 dziećmi; Porte-Saint-Martin zatrudniał 3 pierwszych tancerzy, 5 pierwszych tancerek, a w zespole znajdowało się 14 tancerzy i 14 tancerek oraz 13-ro dzieci.W Ambigu mamy trzy pary pierwszych tancerzy i 10-osobowy zespół, a przy teatrze działała szkoła tańca. ${ }^{40}$

Gérard Gengembre, opisując teatr w długim okresie 1789-1900, tworzy zmienne listy scen bulwarowych - przed rokiem 1791 jest ich 12, po dekrecie 1791 już 47. W 1828 dzieli je na sceny królewskie i prywatne. Te ostatnie to Théâtre de Madame, czyli ex-Gymnase, Le Vaudeville-Nouveautés (na placu Giełdy), Variétés, Porte-Saint-Martin, Gaîté, Cirque Olympique oraz Ambigu-Comique; za nimi idą tzw. Petits Spectacles, wśród których znajdzie się Théâtre de Séraphin (marionetki i cienie), Saqui (akrobaci), Funambules, czy małe Bouffés Parisiens Offenbacha z początkowo pantomimicznymi scenami muzycznymi, w których dialogowały tylko dwie lub trzy postacie. $Z$ tych scen rozwinie się jego operetka, tu nazwana „ostatnim awatarem feerii”"41, główny gatunek nowego, cesarskiego bulwaru.

Mimo kolejnych transformacji scen bulwaru tryumfuje tu wciąż jeden gatunek - wodewil. Narodził sięw XVIII wieku z ,wypolerowanej starej formy skato-

\footnotetext{
38 M. Descotes, Le public..., op. cit., s. 274, 304.

39 P. Bourdieu, op. cit., s. 349.

40 Dane wg P. Ginisty, op. cit., s. 204-206.

41 G. Gengembre, op. cit., s. 74.
} 
logicznej i wulgarnej”, zwanej vau-de-vire, a inspirowanej piosenkami Oliviera Basselin (ok. 1400-1450) z Vire. Z czasem nastąpiła kontaminacja vau-de-vire ${ }^{42}$ i późniejszego określenia voix-de-ville - pisze Daniel Lindenberg, co stworzyło wodewil, początkowo pojawiający się na foirach jako pièce en chansons czy comédie en vaudeville, rozkwitający po 1791 roku. ${ }^{43}$ Niesłusznie zapomniany (jak twierdzi Lindenberg) Eugène Scribe złączył go z dobrze zrobioną komedią intrygi, dokonując literaryzacji kanw i tworząc komedio-wodewil. Według Aleksandra Dumasa-ojca Scribe uczynił taką samą rewolucję w wodewilu, jak on i jego pokolenie w dramacie. ${ }^{44}$ Niezależnie bowiem, jak oceniamy dziś dokonania Scribe'a, które standaryzowały wodewil, był on nowatorem. Jego rola i jego teatru Gymnase jest historyczna, zauważa Gengembre, a teatry wystawiające sztuki ze Scribe'owską marką - więc Gymnase, Variétés i Vaudeville (gdzie odbyła się w 1852 premiera Damy kameliowej Dumasa-syna) stanowiły osobną grupę. Mieszczanin rozpoznawał się tu w swych małych problemach, w swym kulcie pieniędzy, wygodnych iluzjach, w czułostkowości. ${ }^{45}$ Złączony ze swą publicznością tematami dnia, scenami z mieszczańskiej codzienności, powszechnie uznawanymi wartościami wodewil zrobił teatralną karierę. ${ }^{46}$ Tworzyło go wielu autorów, związanych niestabilnymi ,przemysłowymi” spółkami, lecz przede wszystkim miał dwu mistrzów - Eugène Labiche'a i Georgesa Feydeau.

3.

Wyburzenia Georgesa Hausmanna (1852-1870), realizującego idee cesarza, nie tylko zniszczyły stary Paryż, ale też dotychczasowy układ sceny i widowni oraz przygotowały transformację multisystemu - z ludowego na mieszczański. Powstał nowy, drugi Bulwar, którego trwanie badacze rozciągają na okres międzywojenny (dokładniej - do kryzysu lat trzydziestych), choć po Wielkiej Wojnie za sprawą awangardy i Wielkiej Reformy tak radykalnie zmienia się sytuacja teatrów, że skłonna byłabym mówić o dwóch kolejnych bulwarach. Być może pewnym łącznikiem obu okresów jest istnienie Republiki, która zastąpiła Drugie Cesarstwo i związane z nią procesy egalitaryzacji i demokratyzacji społeczeństwa. Jeżeli jednak pod koniec XIX wieku „Europejczycy żyjący wówczas w cenzusowych, autorytarnych i półdespotycznych monarchiach" nie mieli pewności,

42 Oliviera Basselin i jego piosenki zmitologizował Nicolas Brazier, zob. D. Ratajczakowa, Bajka o winie i wodzie. Kilka uwag o muzyce, dramacie i teatrze, [w:] W krysztale i w ptomieniu. Studia i szkice o dramacie i teatrze, t. 1, Wrocław 2006, s. 208, 209.

43 D. Lindenberg, La tentation du vaudeville, [w:] Le théâtre en France du Moyen Age à nos jours, dir. de J. de Jomaron, préface A. Mnouchkine, Paris 1992, s. 678.

44 Cyt. za M. Descotes, Le public..., op. cit., s. 283.

45 G. Gengembre, op. cit., s. 146.

46 Zob. J. Terni, Teatr początków kultury masowej. Francuski wodewil i miasto 1830-1848, przekł. P. Morawski, „Dialog” 2013 z. 1. 
„czy to się utrzyma”, ${ }^{47} \mathrm{w}$ wieku XX sytuacja była inna - mimo kryzysów i afer Republika osiągnęła stabilność. ${ }^{48}$ Inny łącznik, tym razem wewnętrzny, to trwający prymat wodewilu, obok którego rozkwita operetka, komedio-farsa i dramat obyczajowy, co utrzymuje stary podział na dwa komplementarne odłamy już tylko mieszczańskiego teatru: bulwar rozrywki (do której redukuje się często całe zjawisko) i bulwar dramatu. Oba łączyły zarówno „tematy dnia” (modny temat stanowił jeden z czynników atrakcji), jak stabilna forma sztuki dobrze zrobionej, która zabezpieczała mu sukcesy. Oba miały wsparcie ze strony szkoły zdrowego rozsądku, która zastąpiła ,justemilieu” doby Ludwika Filipa. Szkoła odrzuca romantyczną heroizację, przywracając prawa społeczeństwa wymierzone w jednostkę ${ }^{49}$, wykorzystuje „rozwodnione” formy romantyczne, tworząc tak zwany przez Bourdieu „osłodzony romantyzm”. ${ }^{50}$ „Juste millieu” i późniejszą école du bon sens można uznać za dwa warianty francuskiej wersji biedermeieru.

Na przełomie stuleci Bulwar definiuje jednak już inna opozycja - do naturalizmu i symbolizmu, wyznaczających próg wysokich dzieł. Pierwszoplanowe wartości artystyczne i duchowe wytyczały oczywistą granicę między tymi zjawiskami, a Wielkie Bulwary stanowiły wciąż (jak przed laty zauważył Jules Janin) „Bas Ėmpire dramatique”, opozycyjny wobec „Haut Ėmpire”. ${ }^{51}$ Zwłaszcza że na przełomie stuleci dramat zwrócił się ku literaturze - w jego naturalistycznej postaci głównie poprzez drastyczne tematy, takie jak walka płci, prawa silniejszego, zdrada, oszustwa finansowe; w formach powstających pod wpływem symbolizmu czy impresjonizmu otwierał się na kategorie poetyckie.

Lata 1840-1910 to czas kształtowania się nowej przemysłowej klasy robotniczej, odizolowanej od innych klas, stopniowo tracącej związek z ustabilizowanymi formami dawnej ludowej kultury; to czas rozwoju utowarowienia popularnej kultury konsumpcyjnej, hierarchicznej, ale łączącej różne warstwy społeczeństwa. ${ }^{52}$ Ok. 1870, po śmierci teatru dla wszystkich bulwarowy spektakl staje się mieszczańskim produktem luksusowym ${ }^{53}$, homologicznym wobec labiryntu towarów zwłaszcza w wielkich domach handlowych. Powstaje nowa rzeczywistość metropolii, symbolizowana przez dworce kolejowe, wymagająca nowego teatralnego uporządkowania $\mathrm{w}$ obrazach popularnego repertuaru, pośredniczących między odbiorcami a rzeczywistością. ${ }^{54}$ Tryb produkcji dzieł bulwarowych wciąż opiera się na standardowej technice pièce bien faite i często ma charakter spółek autorskich, ale zmienia się styl gry, następuje segregacja widzów związana z za-

\footnotetext{
47 J. Baszkiewicz, Francja nowożytna. Szkice z historii wieków XVII-XX, Poznań 2012, s. 300.

48 Ibidem, s. 312.

49 G. Gengembre, op. cit., s. 144, 145.

50 P. Bourdieu, op. cit., s. 123, 113.

51 C. Naugrette-Christophe, op. cit., s. 35.

52 N. Abercrombie, op. cit., s. 409.

53 G. Gengembre, op. cit., s. 225.

54 C. Naugrette-Christophe, op. cit., s. 388.
} 
porowymi cenami biletów. Po roku 1870 badacz wymienia 26 teatrów, a następnie dzieli je na kategorie według cen miejsc z 1874. Pierwsza kategoria mieści się w przedziale 18 - 2 franki; druga - gdzie należą Vaudeville i Variétés tworzy przedział między 10 i 1,25 franka; trzecia to drogie Porte-Saint-Martin, od 8 franków do 75 centymów i jeszcze droższy Théâtre de la Gaîté (12 franków - 50 cent.). W czwartej kategorii jest nieco taniej - do Folies-Dramatique i Délassements-Comiquewe jdzie się za od 6 franków do 50 cent. Część scen, takich jak Bouffés Parisiens (w pasażu Choiseul), le Dejazet, Porte-Saint-Martin, Gaîté, nawet Odéon oferuje też tańsze bilety, ale nie czyni to z nich scen otwartych dla ludu, zwłaszcza że wiązała się z tym kategoryzacja miejsc. ${ }^{55}$ Ceny pokazują proces elityzacji teatrów, zwyżkowały bowiem ponad $30 \%$. Teraz to teatry mieszczańskie dla mieszczaństwa. Tym samym jednak otwarta zostaje szansa przed jeszcze „niższymi” formami sztuki popularnej, music-hallami i café chantans, które od ok. 1869 zmieniają się w café concerts. Wśród nich te małe, dzielnicowe, mają ceny umiarkowane - między 75 centymów a 3 frankami.

Teatry instytucjonalizują się w oparciu o nową architekturę oraz znamienne dla cesarstwa teatralizacje rzeczywistości, a ich pozycję regulują nowe zwyczaje miejskiej ramy, związanej z prasą i obecną w niej reklamą spektakli, integralnym elementem procesu produkcji i dystrybucji w sieci scen prywatnych. Obrastają one we współpracujące z nimi i płacące im prowizję małe firmy. Rynkiem dramatycznym i krytycznym rządzi Towarzystwo Autorów i Kompozytorów Dramatycznych, które wyewoluowało z Bureau de Législation Dramatique założonego w 1777 z inspiracji Beaumarchais. Podczas prezesury Scribe'a zmieniło nazwę i stało się spółką cywilną, na przełomie wieków prowadził ją Victorien Sardou, bogacąc ją dzięki $10-12 \%$ przychodom ze spektakli. ${ }^{56}$

Najbardziej oczywistym znakiem mieszczańskiego luksusu w erze cesarstwa jest Opera Garniera, pomyślana jako miejsce paradne.

To scena, na której cesarski Paryż przygląda się z lubością samemu sobie; - czytamy u Benjamina - warstwy, które świeżo doszły do władzy i fortuny, pomieszane z elementami kosmopolitycznymi, tworzą ów nowy świat, określany również w nowy sposób: nie mówi się już „Dwór”, mówi się ,cały Paryż”.

Jako miejsce wyróżnione teatr staje się centrum życia towarzyskiego i społecznego. ${ }^{57}$ Teatralizacja rzeczywistości oddziałuje na centra łączące handel $\mathrm{z}$ rozrywką w akcie konsumpcji - zatem na coraz bardziej luksusowe kawiarnie, restauracje, sklepy, a zwłaszcza na wielkie magazyny. Na początku wieku były to „odrealnione budowle ze szkła i żelaza, [...] z fasadami przypominającymi szklane akwaria oplecione fantastycznymi roślinami” (La Samaritaine z 1906, Le

55 Ibidem, s. 217, 218, 219.

56 S. Jakóbczyk, Na Zachód ze Wschodu. Savoir i Kessel w nowoczesnym przemyśle literackim, Poznań 2005, s. 70-72.

57 W. Benjamin, op. cit., s. 455. 
Printemps z 1907). Z lat 1906-1907 pochodzi budynek Galeries Lafayette. „Jego główny hol zwieńczony szklaną kopułą, ozdobiony złoconymi sztukateriami i witrażami przerasta wszystkie przepyszne wnętrza domów towarowych, jakie zbudowano w Europie". ${ }^{58}$ Można go porównać jedynie z operą Garniera.

Najbardziej pożądanym towarem na Bulwarze jest nadal wodewil, który staje się wieloodmianowym gatunkiem - może być polityczny, bachiczny, anegdotyczny, farsowy, feeryczny, może być subtelny lub rubaszny, nawet ,śliski” (grivois), mieć formę folies-vaudeville, folies-parades en vaudeville; po 1880 staje się też militaire.$^{59}$ Gatunek oblicza się dziś na ok. 10 tys. utworów, z tego wiele w jednym akcie, powstających przy współpracy więcej niż dwu autorów, specjalizujących się $\mathrm{w}$ dialogach, sytuacjach, wątkach. ${ }^{60}$ Była to prawdziwa produkcja przemysłowa, odpowiadająca czasowi industrialnemu, strukturowana poprzez schemat intrygi i różne formy wprowadzania chwilowego nieładu - jak nieprawdopodobne zwroty akcji, niezwykłe sytuacje, przebrania, kłamstwa, imbroglio, qui pro quo.

Ok. 1858 rodzi się operetka. Muzyczność obu form kreuje dwu mistrzów. Pierwszy to Jacques Offenbach, zwany „Mozartem z Pól Elizejskich” ${ }^{61}$ Drugi to następca Eugène'a Labiche'a, Georges Feydeau, zwany „Mozartem wodewilu”. ${ }^{2}$ Pierwszy w 1866 wystawił Życie paryskie, „najbardziej uroczy ze wszystkich hymnów skomponowanych na cześć miasta"63; drugi jest twórcą słynnej Damy od Maxima (1898), która była symbolem życia paryskiego na początku XX wieku. „Machine de précision” - tak Guy Leclerc określa wodewil Feydeau. Wprowadza on na scenę postacie rzeczywiste, jakie można spotkać w salonach, na ulicach czy w teatrach i wplątuje je w ekstrawagancką historię pełną nieprzewidzianych wydarzeń i qui pro quo pojawiających się zgodnie z rygorem matematycznym. ${ }^{64}$

Te „skandaliczne”, ślizgające się po powierzchni rzeczywistości czysto rozrywkowe formy, są produktem ,wyizolowanej kultury miejskiej”65, a operetka według Karla Krausa - akceptuje świat, w którym „wszelki nonsens zrozumiały jest sam przez się, nigdy nie wywołując racjonalnych reakcji”. ${ }^{66}$ Obok nich kwitnie trzecia postać rozrywki, komedio-farsa, na której bawiono się, ,nie sprawdzając gatunku towaru”. ${ }^{67}$ Popularne formy wypełniały ,puste teatralne miejsce po rzeczywistości”, choć operetkę Offenbacha uznaje Kracauer za „coś więcej niż wesołą rozrywkę". Widzi w niej zrodzoną ze sceptycyzmu satyryczną i frywolną formę protestu przeciw belle époque. Wszystkie te formy (poszerzone o dramat)

\footnotetext{
58 M. Omilanowska, op. cit., s. 248-249.

59 A. Pierron, Dictionnaire de la langue du théâtre. Mots et moeurs du théâtre, Paris 2002, s. 592.

60 G. Gengembre, op. cit., s. 282.

$61 \quad$ S. Kracauer, op. cit., s. 134.

62 H. Gidel, Georges Feydeau, Paris 1991, s. 37.

63 Ibidem, 226.

64 G. Leclerc, Les grandes aventures du théâtre, préface J. Vilar, Paris 1965, s. 258, 259.

65 S. Kracauer, op. cit., s. 162.

66 Cyt. za B. Grun, Dzieje operetki, przekł. M. Kurecka, Kraków 1974, s. 159.

67 K. Troczyński, Pisma teatralne, oprac. D. Ratajczakowa, Kraków 2000, s. 229.
} 
współtworzyły ówczesną postać kultury popularnej i bulwaru, ulubionego miejsca outsiderów z nowej bohemy, birbantów i półświatka z kawiarnianych ogródków z piosenkami ${ }^{68}$ Wszystkie też znalazły się na estetycznym dnie za sprawą wysokiego modernizmu.

W 1882 roku na 26 sal teatralnych trzy permanentnie grały wodewile - le Palais-Royal, les Nouveautés i l' Athéneée-Comique, a 7 dalszych też często je wystawiało - le Gymnase, le Vaudeville, les Variétés, la Renaissance, le Cluny, les Menus-Plaisirs, le Dejazet. ${ }^{69}$ Bulwarowa publiczność przełomu wieków uczyniła z wodewilu przedmiot uprzywilejowanej kulturalnej konsumpcji ${ }^{70}$, traktując go ,jako pełną i zamkniętą w sobie formę rozrywki". ${ }^{71}$ Tę szczelną barierę wodewilu i komedii intrygi (Tristana Bernard, Flersa i Caillaveta, Verneuila i innych) tworzącą sztuczny świat beztroski i zabawy charakteryzuje ,pomysłowość, elegancja, pobłażliwy sceptycyzm, zręczne dozowanie śmiechu, emocji i zmysłowości”. ${ }^{72}$ Postacie z tych sztuk prowadzą przyjemne, łatwe życie i nigdy nie zapominają być dowcipne.

Poza barierę czystej rozrywki przedostała się z początkiem wieku poważniejsza komedia i dramat, pozornie podejmujący poważniejsze problemy. Były to utwory modnych autorów, grawitujące teraz ku literaturze i ożywiające (w bulwarowym wydaniu) francuską tradycję analizy psychologicznej. Stanowiły one przede wszystkim rezultat zręcznej, efektownej dramaturgii, adresowanej do publiczności, która - jak pisał znający dobrze bulwarową widownię Jan Lorentowicz -

chwyta w lot wszystkie aluzje, intensywnie uczestniczy w akcji, a nastrojem, jaki w teatrze wytwarza, pomaga aktorowi do wydobywania z poszczególnych epizodów wszelkich zasobów komizmu, dramatu lub po prostu - marzenia. Nie ginie w teatrze ani jedna sytuacja, ani jedno słowo sztuki; $[\ldots]$ wszyscy p r z e r a b i a ją z autorem zatargi i rozwiązania dramatyczne. ${ }^{73}$

Autorzy ci, ich dramaty oraz przede wszystkim ,specjalny gatunek publiczności paryskiej" ${ }^{74}$ stanowili łącznik między czasem przed Wielką Wojną, a dwudziestoleciem. Jeden z nich, Henri Bernstein, specjalista od gwałtownych i efektownych namiętności, złożył specyficzny hołd staremu melodramatowi, który kończąc żywot wraz z wiekiem XIX, rozproszył się po innych mediach, zwłaszcza po filmie i powieści. Dramat nazwany po prostu Mélo, był historią dwóch przyjaciół i żony jednego z nich, trującej powoli męża z miłości do tego drugiego.

Po tzw. Wielkiej Wojnie trwa dobra passa Bulwaru, choć działa on już w nowych warunkach. Po pierwsze sytuuje się nie tylko wobec teatrów subwencjono-

68 S. Kracauer, op.cit., s. 187-190.

69 D. Lindenberg, op. cit., s. 677.

70 M. Corvin, Le boulevard en question, op. cit., s. 845.

71 B. Grun, op. cit., s. 159.

72 P. Surer, Wspótczesny teatr francuski. Inscenizatorzy i dramatopisarze, przekł. K. A. Jeżewski, Warszawa 1973, s. 30.

73 J. Lorentowicz, Henryk Bataille, ,,Ptaszyna”, [w:] Dwadzieścia lat teatru, t. 2, Warszawa 1930, s. 323.

74 Ibidem, s. 328, tu recenzja Nagiej kobiety. Lorentowicz zapewne nie lubił tej widowni, zresztą zgodnie z ideami wrogiego komercji wysokiego modernizmu. 
wanych, ale także wobec obrazoburczych działań Antonina Artauda, ożywczych poczynań Jacques'a Copeau oraz inspirowanych przez niego i idee Wielkiej Reformy Kartelu Czterech, zatem artystycznych scen Charles'a Dullina, Louisa Jouveta, Gastona Baty'ego i Georges'a Pitoëffa. Budują one pole dla nowego, nietradycyjnego dramatu poetyckiego czy intymistycznego. ${ }^{75} \mathrm{~W}$ tym nowatorskim kręgu pojawią się sztuki Pirandella czy Crommelyncka. Ale to nie wszystko. Już wtedy zaczął się proces o daleko idących konsekwencjach - jak zauważa Jacques Derrida, „Europa połączyła swój obraz [...] i samo swe miejsce, samo swe wydarzenie z obrazem szpicy, przedniej straży", zatem z ideą awangardy jako nowego początku sztuki, jej celu i granicy. ${ }^{76}$ Tradycyjny kształt związku dramatu i teatru atakują teraz różne odłamy awangardy, a obok nich rozkwitają takie media, jak kino, radio, czy mająca już własne tradycje fotografia, publikowana w ilustrowanej prasie i przemysł pocztówkowy. Co w tej sytuacji komercyjny Bulwar oferuje autorom, aktorom, widzom i teatrom, które funkcjonują w powstałym wcześniej niejako własnym kontekście widowisk rozrywkowych - caf'conc., wystawnych music-halli, kabaretów. Odpowiedź jest prosta - oferuje pieniądze.

Do kryzysowych lat trzydziestych XX wieku pojawia się tu 50 nowych sztuk w każdym sezonie ${ }^{77}$, a autor może zarobić 10-30 tys. rocznie. Jest to bowiem wciąż inwestycja niskonakładowa. ${ }^{78}$ Nie dziwi więc, że Patrice Pavis pisze o ówczesnej drugiej świetności bulwaru, podobnie Michel Corvin wspominający o intensywnej produkcji sztuk, o znakomitych aktorach. ${ }^{79}$ Wydaje się, że jest to wciąż ten sam bulwar, o trwającej świetności. Oba oblicza bulwaru, rozbawione i poważne, łączy zarówno wierność widowni, jak wierność starym sposobom tworzenia - zatem retoryka, koncentracja efektów, redundancja, nasilenie ekspresji, symetrie i opozycje ${ }^{80}$, a także katalog chwytów - „trzecich aktów”, słynnych „słów autorskich”, różnych „scenes a faire”, „wybornych zakończeń”. Pod presją nowych prądów zaczyna się jednak liczyć pewien stopień oryginalności i stylistyczna rozmaitość. Teksty uatrakcyjniają nowe elementy pożyczone z radia i filmu, które same stają się towarem. Pożądany tryb dystrybucji oblicza się na 5 tygodni nieprzerwanego grania, kiedy to utwór staje się „sztuką dnia”. Sukces bulwaru zapewniają monopolistyczne praktyki Towarzystwa Autorów i Kompozytorów Dramatycznych. ${ }^{81}$ Rację ma jednak Bourdieu, stwierdzając, że „nic nie dzieli twórców kulturowych tak wyraziście, jak stosunek do sukcesu komercyjnego czy też sukcesu odnoszonego „w świecie”. ${ }^{82}$ Są to bowiem dwa różne sukcesy.

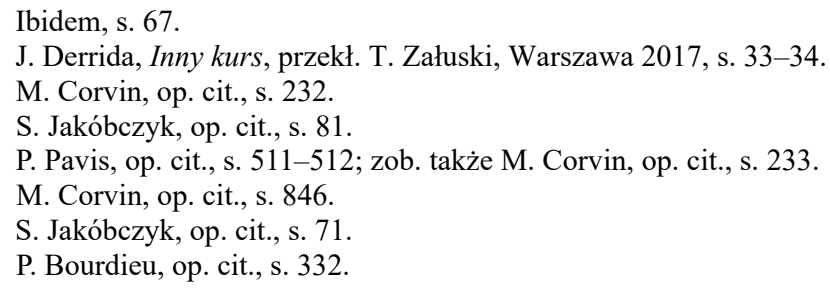


4.

Druga wojna tylko pozornie nie zaszkodziła spektaklom bulwarowym, zwłaszcza pozycji Sachy Guitry'ego (zresztą syna świetnego aktora bulwarowego, Luciena), którego sztuki w międzywojniu grano niemal bez przerwy - w La Renaissance, Les Variétés, Le Gymnase i Le Vaudeville, Le Porte-Saint-Martin i Odéonie. ${ }^{83}$ Był on traktowany jak „król teatru”, „Ambassadeur de l'Esprit francais”. Wiązało się to $\mathrm{z}$ faktem, iż Bulwar był dostarczycielem repertuaru dla wielu scen w Europie, znajdując się jakby na centralnej krzyżówce dróg dramatu. Pewien własnej pozycji, nie zgadzając się na przymusową wojenną marginalizację, Guitry w sześć tygodni po upadku Paryża za zgodą władz niemieckich otworzył premierą Théâtre de la Madeleine ${ }^{84}$, za co musiał później ponieść pewne konsekwencje.

Po wojnie sytuacja bulwaru zmienia się znacząco. Jego struktura wciąż istnieje, funkcja zostaje, mimo że z wielu powodów jego pozycja ulega zmarginalizowaniu. Przede wszystkim oddziałuje niekorzystnie akt oficjalnej konsekracji awangardy i pojawiającego się w latach pięćdziesiątych na szczytach sztuki teatru absurdu. Ma on własnych poprzedników, własne wielkości, własne formy i idiom sceniczny, swych następców - a przede wszystkim inny system wartości, który neguje (i karykaturuje) wartości Bulwaru.

Zmieniły się również warunki pracy teatrów. Raymonde Temkine podaje przykład starego Ambigu, który w 1955 wziął Christian Casadesus z intencją przywrócenia go do dawnej świetności. Ale nowy dyrektor nie wytrzymał presji koniecznych a kosztownych przeróbek, jakich wymagało doprowadzenie teatru do aktualnego poziomu instytucji rynkowej, zarówno pod względem zasad bezpieczeństwa, jak i unowocześnienia oświetlenia i dżwięku. Kalkulacje okazały się zbyt optymistyczne, a 1000 miejsc nie pozwalało go uznać za teatr ludowy (optymalne dla takiej sceny to 1500 miejsc), ani za bulwarowy (tu optimum - to 600) ${ }^{85}$

Wydarzenia roku 1968 ożywiają tradycje rewolucyjnej Francji, a maj paryski ocenił Edgar Morin jako ,aspirację do innego życia, innego społeczeństwa, innej polityki" ${ }^{86}$ Ujawnił się wtedy kryzys władzy, cywilizacji, szkolnictwa, sztuki teatru. W latach 1970-1990 dokonuje się jej transformacja. Znakiem czasu stają się przenosiny Petera Brooka z Anglii do Paryża, gdzie (wraz z Micheline Rozan) w 1971 zakłada Międzynarodowy Ośrodek Poszukiwań Teatralnych, po paru latach przekształcony w Ośrodek Twórczości, realizujący spektakle w międzynarodowych, wielojęzycznych obsadach. Wprawdzie ,główny nurt” i Bulwar pozostają przy tradycyjnych salach, ale rzeka poszukiwań wprowadza teatralne wydarzenia do hangarów, starych dworców, fabryk, uruchamia ateliers i laboratoria, rozbija

83 G. Gengembre, op. cit., s. 855.

84 A. Riding, A zabawa trwała w najlepsze. Życie kulturalne w okupowanym Paryżu, przekł. P. Tarczyński, Warszawa 2012, s. 70.

85 R. Temkine, L'éntreprise théâtre, Paris 1967, s. 29-30.

86 Cyt. za J. Baszkiewicz, op. cit., s. 342. 
tradycyjną konstrukcję dramatu. Na topie będą teraz różne poszukiwania i postacie eksperymentu - dla Patrice Pavisa stanowiące odmiany teatru „szlachetnego”. Tym samym Bulwar zostaje zaklasyfikowany jako „nieszlachetny”, sprowadzony do rozrywki „nie wymagającej zbytniego wysiłku intelektualnego” i ograniczonej do lekkich komedii ,niezbyt oryginalnych i niezbyt szokujących”, utrzymanych w poetyce powierzchownego „salonowego naturalizmu”. Wprawdzie nadal ma swą mieszczańską i drobnomieszczańską widownię „o tradycyjnym guście estetycznym i konserwatywnej świadomości polityczno-społecznej" ${ }^{87}$, ale wciąż jest „towarzyskim teatrem na wesoło, gdzie wszystko zawsze kończy się fatalnym (i trochę nieznośnym) happy endem". Bruno Koper przeciwstawi Bulwar nie tylko awangardzie i kontynuacjom ruchu reformy teatru, ale też fali café-teatrów. Bulwarowe sceny określi jako,teatr kryzysu inteligencji i wyobraźni”, „pigułkę uspokajającą i pseudo-kulturalny środek nasenny" dla jego widzów. ${ }^{88}$

Po „drugiej stronie lustra” zasadnicza zmiana dokonuje się na płaszczyźnie konsumpcji - od roku 1953, kiedy to powstaje Eurowizja, przekształceniu ulegają konsumpcyjne wzory, przemysł kulturowy uwalnia pragnienia i pożądania na ogromną skalę. W latach osiemdziesiątych zaczynają powstawać „wielkie przedsięwzięcia handlowo-rozrywkowe, łączące produkcję kolejnych części kinowej serii ze sprzedażą zwielokrotnionego wizerunku filmowych postaci w niekończącym się ciągu komiksów, książek, gier komputerowych, gadżetów, seriali telewizyjnych itd.". Zjawisku nadano nazwę supersystemu rozrywkowego ${ }^{89} \mathrm{~W}$ tym kontekście dawny supersystem Bulwaru wydaje się po prostu przestarzały. Cóż, że proponuje (jak zwykle) spektakle dobrze zrobione, oparte o aktualne tematy i wydarzenia, że oferuje świat oczekiwany o względnie stałych wartościach, skoro pole komercji, na którym funkcjonuje, utraciło polor nowoczesności.

Jak w istniejącej dziś rzeczywistości kulturowej usytuować jego współczesną postać, z typem prywatnego rozrywkowego teatru i tradycyjnym popularnym i komercyjnym repertuarem? Nad jego „być” albo „nie być” zastanawia się Michel Corvin, stawiając znak zapytania przy jego zdolności do odrodzenia. Wprawdzie lista wszystkich scen paryskich z 1975 roku obejmuje 75 teatrów, 17 café-théâtres, 6 music-halli i sceny usytuowane w miejscach nie-teatralnych ${ }^{90}$, ale Corvin obserwuje regres Bulwaru. Tam, gdzie kiedyś działało 10 teatrów, dziś mamy pięć podaje za Pierre Laville (1982) ${ }^{91}$ : to le Palais-Royal, les Variétés, Antoine, les Nouveautés, le Madeleine. Bulwar się jednak nie poddaje. W latach dziewięć-

87 P. Pavis, op. cit., s.511, 512.

88 Korespondencja z Paryża. B. Koper, Kryzys teatru czy teatr kryzysu, „Student”1978 nr 4 (23 II-3 III).

89 Zob. Z. Wałaszewski, Papierowy jednorożec, klubówka i,, Łowca androidów’. O powstawaniu supersystemu rozrywkowego, [w:] Literatura i kultura popularna. Badania, analizy, interpretacje, red. A. Gemra, Wrocław 2015, s. 220.

90 M. Versillier, op. cit., s. 38.

91 M. Corvin, op. cit., s. 886. 
dziesiątych wciąż działają wymienione przez Laville'a teatry, a obok nich Théâtre Eduard VII - Sacha Guitry, Porte-Saint-Martin czy Renaissance. ${ }^{92}$ Podobnie jest dziś - w sezonie 2016/17, gdy prócz poprzednich grają Dejazet, Hebertot, Porte-Saint-Martin i inne, a Bulwar reklamuje się jako „,bulwar śmiechu”, pokazujący głównie komedie i farsy, a zamiast wodewilu i operetki - operę pop-rock i musicale ${ }^{93}$ przerobione z wielkich powieści. Czyżby o jego trwaniu decydowała wciąż siła jego tradycji i przyzwyczajeń widowni, dając mu pozór zjawiska, które jest trochę żywe i trochę martwe zarazem?

92 Zob. L'Actualité du théâtre contemporain d'expression française. Saison 1993/94, Paris 1994.

93 Zob. Guide des spectacles à Paris en 2016-2017: evous.fr/Guide-des-spectacles-a-Paris 1185091.html. 